\title{
The influence of low versus high fibre haylage diets in combination with training or pasture rest on equine gastric ulceration syndrome (EGUS)
}

\author{
Maarten Boswinkel', Andrea D. Ellis ${ }^{2}$ and Marianne M. Sloet van Oldruitenborgh-Oosterbaan' \\ Department of Equine Sciences, Faculty of Veterinary Medicine, Utrecht University ${ }^{\text {}}$ and School of Animal Rural and Environmental Sciences, Nottingham Trent \\ University, UK²
}

\begin{abstract}
Summary
The aim of this field study was to examine the influence of a low fibre (LF) and a high fibre (HF) diet on the presence of gastric ulceration in thirty 3-year old Dutch Warmblood horses during training period and during pasture rest. In the first part of the study all horses were stabled individually and fed either an iso-energetic HF ( $75 \%$ haylage) or LF ( $25 \%$ haylage) diet for sixteen weeks. Horses were exercised daily throughout this period, after which the first gastroscopy was performed. The second gastroscopy for all horses was performed following a fourteen week Pasture period during which grass was supplemented with haylage. Contrary to expectations the scores for number and severity of gastric lesions during the Training period were significantly higher in the HF group compared to the LF group. Additionally, horses of the HF group showed high haylage retention in the stomach after 12 hours fasting, whilst the LF group exhibited marked bedding eating and coprophagia. The results of gastroscopy following the Pasture period with extra haylage feeding for all horses, were similar to the HF horses following the Training period. These unexpected results may be related to the retention of the pre-fermented feed (haylage) in the stomach leading to continuing fermentation with increased volatile fatty acid (VFA) production in the stomach. The consumption of bedding and coprophagy shown by the LF group may have limited the previously reported high risk of gastric ulceration on a lowfibre diet.
\end{abstract}

Keywords: gastric ulceration, haylage, diet, horse, fibre

Zum Einfluss einer rohfaserreichen im Vergleich zu einer rohfaserarmen Fütterung in Kombination mit Training oder Weidegang auf Magenulkussyndrom des Pferdes (EGUS)

Im Rahmen eines umfangreichen Experiments wurde der Einfluss von einer rohfaserreichen (RR) oder rohfaserarmen (RA) Diät auf die Magengeschwürbildung bei dreißig 3-jahrigen Holländischen Warmblutpferden durchgeführt. In der ersten Phase (16 Wochen) waren Pferde in Einzelboxen aufgestallt und sie erhielten entweder 75\% der Diät als Trockensilage (Haylage, RR Gruppe) oder 25\% der Diät als Haylage (RA Gruppe). Die Diäten waren isoenergetisch eingestellt. Kraftfutterpellets für Sportpferde bildeten den zweiten Teil der Diät. Die Pferde wurden in gleicher Weise bis zu mittelschwerer Arbeit trainiert und am Ende der Periode wurden sie einer gastroskopischen Untersuchung unterzogen. Nach einer darauffolgenden 14 -wöchigen Zwiwchenzeit, die alle Pferde auf der Weide verbrachten, fand der zweite Teil der Studie statt. Nun wurde Haylage ad libitum beigefuttert. Entgegen der Erwartungen entwickelten während die Trainingperiode die RRPferde eine signifikant größere Zahl an Geschwüren und höhere Hyperkeratinose-Scores als die RA-Pferde. Bemerkenswert war auch, dass sich in die Mägen der Pferde der RR-Gruppe noch nach 12 Stunden fasten noch eine Menge Haylage und bei den RA-Pferden eine Menge an Holzspänen und auch eigenen Mist fand. Nach der Weideperiode waren die Resultate aller Pferde ähnlich der RR-Resultate. Zwei mögliche Hypothesen können die Resultate erklären. Zum einen könnte die unerwartete Retention schon vorfermentierter Haylage im Magen zu vermehrter Fermentation mit erhöhter Produktion von flüchtigen Fettsauren und Milchsäure in diesem ungewohnten Bereich geführt haben. Zum andern ist es denkbar, dass bei solch rohfaserarmen Diäten die Aufnahme von Holzspänen und Dung zu einer Säuerung des Magens mit Bildung von Geschwüren führt. Diese Theorien müssen weiter untersucht werden.

Schlüsselwörter: Fütterung, Pferdediät, Magengeschwüre, Silage, Rohfaser

\section{Introduction}

Equine gastric ulceration syndrome (EGUS) is a prevalent disorder in performance horses and foals (Bertone 2000, Coenen 1992, Deegen et al. 1992, Dörges et al. 1995, Lundberg et al. 1996, McClure et al. 1999, Murray 1989, Murray et al. 1990, Murray et al. 1996a, Murray et al. 2001, Rabuffo et al. 2002, Vatistas et al. 1999). Most previous studies have been undertaken in Thoroughbred and Standardbred horses. The diagnosis of gastric ulceration in horses is based on history, clinical signs, gastroscopy and the beneficial response to specific anti-ulcer treatment. Symptoms, which can accompany EGUS, include reduced appetite (possibly even anorexia), acute often recurrent colic signs, poor performance and body condition and changes in temperament due to pain and discomfort.

Factors that damage the gastric mucosa such as decreased $\mathrm{pH}$ due to diet or intensive exercise, and decreased mucosal 
protection (mucus and bicarbonate reduction) have been implicated as causative factors for EGUS (Cambell-Thompson and Merritt 1990, Murray 1994). In adult horses most gastric ulcers develop in the squamous epithelial mucosal lining. This is suggested to be due to a lesser protective capacity against peptic injury in this area. In contrast to the glandular mucosa, the squamous epithelial mucosa is not protected by a mucus layer, which serves as a protection against the influence of acid (Andrews et al. 1999, Ross et al. 1981). Periods of fasting, during which the gastric mucosa is exposed to highly acidic conditions due to a constant production of acid in the horse's stomach, are a direct threat to the protective barrier function of the gastric epithelium.

Intensive exercise, feed management, illness and certain stress factors play a role in the multifactorial aetiopathology of gastric ulcers (Andrews et al. 1999, McAllistair et al. 1997, Murray et al. 1996a)

Dietary factors have also been implicated in the formation of EGUS. Research into feed management as a possible risk factor, showed that feed deprivation for 24 hours resulted in a median gastric $\mathrm{pH}$ of 1.6, compared with a median $\mathrm{pH}$ of 3.1 when horses had ad libitum access to hay for 24 hours (Murray and Schusser 1993). High-concentrate diets contain high amounts of digestible carbohydrates, which are broken down enzymatically in the stomach and small intestine and absorbed as glucose and fructose. Generally there is less buffering from saliva during rapid ingestion of concentrate feeds (Meyer at al. 1980) and acidity in the stomach rises during prolonged intervals between meals (Feige et al. 2002, Murray 1994, Murray and Schusser 1993). This is believed to be a key factor in the aetiology of clinically significant stomach ulcers in animals on low fibre diets, (Cambell-Thompson and Merrit 1990, Hammond et al. 1986).

Apart from the damaging effect of $\mathrm{HCl}$ on stomach lining, the spectrum of volatile fatty acids (VFA's) has recently been implicated as a contributory factor (Nadeau et al. 2000 and 2003). A diet comprising grain and alfalfa hay induced both a significantly higher $\mathrm{pH}$ and increased concentrations of acetic, propionic and isovaleric acids in the gastric content compared to a diet of grain and brome grass hay, which induced a lower $\mathrm{pH}$ and higher levels of butyric and valeric acids (Nadeau et al. 2000). In this study the number and severity of gastric ulcers was significantly lower in the alfalfa group. The higher protein and calcium contents of alfalfa probably acted as buffers in the equine stomach (Nadeau et al. 2000). An in vitro study showed that exposure of gastric mucosa to acetic, butyric and proprionic acid under low $\mathrm{pH}$ conditions ( $\mathrm{pH} \leq 4.0)$ led to a decreased mucosal barrier function in the saccus caecus region (Nadeau et al. 2003). Nadeau et al. (2003) concluded that this is probably due to the VFA's penetrating cells in the non-glandular gastric mucosa, causing acidification of cellular contents, inhibition of sodium transport, and cellular swelling. Lactic acid and VFA's are produced by microbial activity in the fundic region, and although de Fombelle et al. (2003) isolated relatively few cellulytic bacteria, a considerable amount of lactobacilli, streptococci and lactate-utilisers were found. The extent of VFA production in the equine stomach is linked to the fermentability of ingested carbohydrates (de Frombelle et al. 2003).
Earlier investigations have shown that horses in training have a high prevalence of gastric mucosal ulcers, and that these worsen during training (Murray et al. 1996a, Roy et al. 2005). A prevalence of up to $70 \%$ of gastric ulceration has been reported in racehorses (Hammond et al. 1986). In addition to intensive workloads, these horses are commonly fed high-concentrate low-roughage diets, which have been implicated as one major factor in the cause of EGUS (Hammond et al.1986). The effect of different diets on the development of EGUS in non-racing horses has not been investigated previously.

To test the hypothesis that a low-fibre diet induces a higher gastric ulceration score than a high-fibre diet, gastroscopy was performed to evaluate the effects of a high-fibre and a low-fibre diet on the presence of squamous gastric ulcers at the end of a three month training programme and following a subsequent three month pasture period. The study was part of a larger project to measure the effect of diet composition and training on digestibility and behaviour.

\section{Materials and Methods}

Experimental Design

This study was part of a much larger experiment, in which the effect of three exercise levels and related increased energy intake on behaviour and digestibility were investigated (Ellis et al. 2003, Ellis et al. 2006). The main study included 30 horses, but one horse was excluded because its stomach was too full even after several fasting periods to evaluate the presence of ulceration. Thus, twenty-nine 3-year old Dutch Warmblood horses (sixteen geldings and thirteen mares; body weight $554 \pm 42 \mathrm{~kg}$ ) were used in the present study.

The experimental period was divided into a 16-week 'Training period' at a HF diet or at a LF diet and a further 14-week period at pasture ('Pasture period'). After both periods a single gastroscopy was performed on each horse.

The times of the gastroscopies may not have always been optimal, but these times were the only possible opportunities presented. It was also not possible to randomise the individual horses to the HF- or LF-groups based on their 'pre-experimental' gastroscopy scores or to perform a cross-over design for both treatment groups. To meet with this practical inadequacy a consistent group of horses was chosen, in which age, breed, and history (nutrition, housing) from birth were similar and each individual horse acted as its own control between the two phases (Training period and Pasture period).

\section{Diet and exercise}

Training period

Horses were blocked according to sex and then randomly assigned into a high fibre (HF) (dry matter (DM) ratio - concentrate : haylage $=1: 4, \mathrm{n}=15$ ) and a low fibre (LF (DM ratio - concentrate: haylage $=4: 1, n=14$ ) feed group during the Training period. The concentrate pellets were designed for performance horses and had a starch and sugar content of $32 \%$. The word 'fibre' within the trial refers 
Table 1 Work levels during Training period and daily exercise on high speed horse walker. Arbeitsniveau während der Trainingsphase.

\begin{tabular}{|c|c|c|c|c|c|c|}
\hline \multirow[t]{2}{*}{ Week } & \multirow[t]{2}{*}{ Exercise Level } & \multirow[t]{2}{*}{ Energy-requirements* (x maintenance) } & \multicolumn{4}{|c|}{ Horse walker (minutes/day) } \\
\hline & & & Walk & Trot & Canter & Total \\
\hline $1-4$ & Light & 1.2 & 18 & 10 & 5 & 33 \\
\hline $5-9$ & Medium & 1.3 & 22 & 15 & 8 & 45 \\
\hline $10-16$ & Medium-heavy & 1.5 & 21 & 36 & 15 & 72 \\
\hline
\end{tabular}

to 'structural fibre' which has not been chopped or ground down through processing. During the Training Period, horses were trained over a 16-week period in a high-speed horse walker and on a high-speed treadmill in three consecutive phases (Table 1). The first two phases lasted 4 weeks each, whereas the third phase lasted 8 weeks. During the Training period all horses were fed an iso-energetic in relation to exercise expenditure per phase diet according to the Dutch net energy system (Centraal Veevoederbureau 1996). Haylage (dry rye grass silage - dry matter 58\%) was offered twice daily (08:00 hours and 17:00 hours), while concentrate feed was divided into three equal meals (08:00, 13:00 and 17:00 hours) for both groups. A minimum of $1.4 \times$ requirements of digestible crude protein was fed to all horses in order to keep protein intake as similar as possible. The HF group was fed an additional mineral supplement in order to approximate mineral intakes to those concentrations fed in the LF group. By phase 3 of the training the HF group was being fed a total of 12-13 kg wet matter (WM) haylage and $3 \mathrm{~kg}$ WM concentrate, compared to the LF group which received 2-3 kg WM haylage and $7 \mathrm{~kg}$ concentrate. The horses were individually stabled on a shavings bedding with free access to fresh water.

Pasture Period

Following the Training Period all horses were turned out onto grassland for 14 weeks (Pasture Period). Geldings and mares were kept separately. Due to the extremely dry summer all horses received additional haylage at pasture, to maintain body condition. The feeding regime for the Pasture Period diet was, therefore, grass and haylage. Exact haylage intake per horse could not be determined, but an average of $11 \mathrm{~kg}$ WM was fed per day per horse.

\section{Gastroscopic examination and scoring}

At the end of both periods, all horses underwent a single gastroscopic examination after a fasting period of at least 12 hours and a minimum 3 hour period of water deprivation, using $325 \mathrm{~cm}$ (working length) flexible video-endoscope (Xion PV-G $300^{\circledR}$, Xion Medical GmbH, Berlin, Germany).

During the Training Period horses were individually stabled for fasting, while during the Pasture Period horses were kept on concrete yards for fasting. Muzzles were used to prevent the horses from eating bedding in the stables during fasting. Fifteen minutes prior to gastroscopy, horses were sedated with $0.01 \mathrm{mg} / \mathrm{kg}$ detomidine (Domosedan ${ }^{\circledR}$, Pfizer Animal
Health B.V., Capelle aan de IJssel, The Netherlands) by intravenous injection. Horses were led into stocks and a twitch was used for further restraint where required.

The entire squamous and glandular mucosa of the stomach was examined on each occasion and scored for amount of lesions and severity of lesions according to the method by MacAllister et al. (1997). Additionally, a score on the amount of hyperkeratosis of the squamous mucosa was performed ('hyperkeratosis score') and a 'total clinical score' was given.

Amount of lesions

Scoring of amount of lesions based after MacAllister et al. (1997) means: $0=$ no lesions; $1=1-2$ lesions; $2=3-5$ lesions; $3=6-10$ lesions; $4=>10$ lesions.

Severity of lesions

Scoring of severity of lesions after MacAllister et al. (1997) means $0=$ no lesions; $1=$ appears superficial (only mucosa missing); $2=$ deeper structures involved (greater depth than no.1).

\section{Hyperkeratosis}

Scoring of hyperkeratosis of the squamous mucosa used for this study: $0=$ no hyperkeratosis, 1 = slight hyperkeratosis, 2 = moderate hyperkeratosis, 3 = severe hyperkeratosis, 4 = extensive hyperkeratosis (Figure 1 A-D).

Clinical score

Overall clinical score of gastric ulceration is a clinical evaluation of the stomach during gastroscopy. This scoring takes into account: the amount of lesions, the dept of the lesions and the amount of hyperkeratosis and is used clinically to predict whether a patient is likely to have clinical signs of EGUS. In this scoring: 0 = no changes at all, 1 = slight changes (a little erosions and/or a little hyperkeratosis), 2 = a few very superficial erosions or one slightly deeper erosion and some hyperkeratosis, $3=$ many superficial erosions or a few deeper lesions and/or moderate hyperkeratosis, and $4=$ severe lesions and hyperkeratosis, and such a horse is likely to show clinical signs.

All gastroscopic examinations were recorded and scored by the first author. A second veterinarian (last author) subsequently assessed all the recorded tapes independently. Both veterinarians were blind to HF or LF groups. 

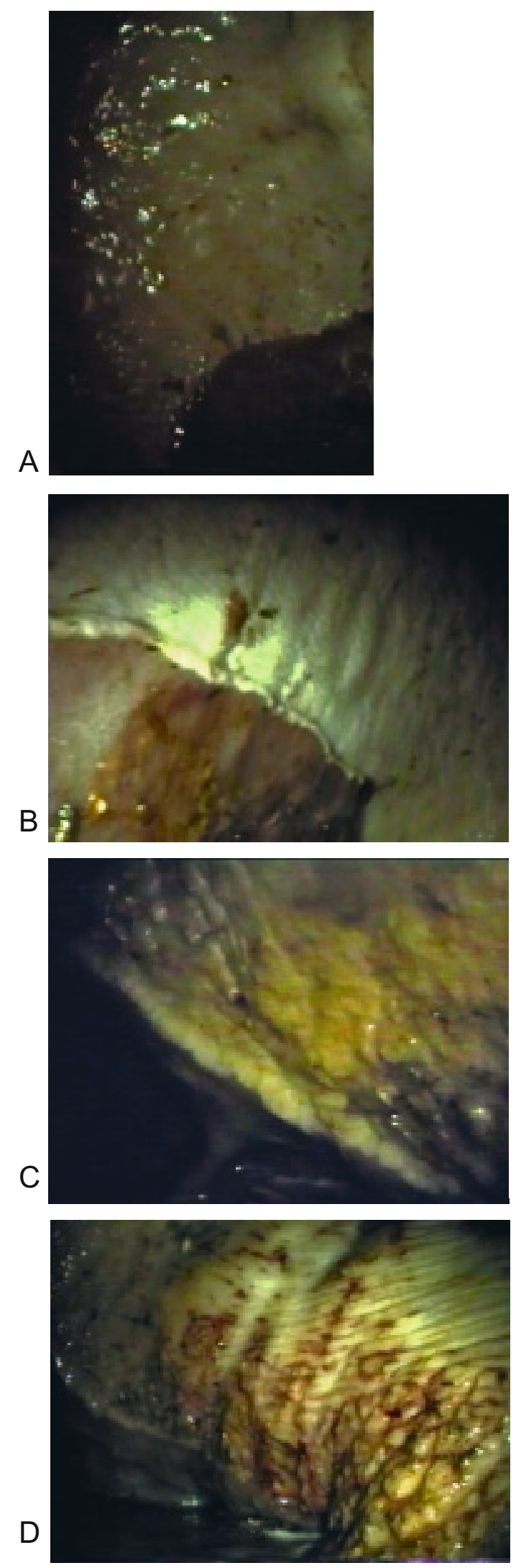

Fig 1 Hyperkeratosis scoring used in 29 3-year old Dutch Warmblood horses. $\mathrm{A}=1$ = slight hyperkeratosis, $\mathrm{B}=2=$ moderate hyperkeratosis, $\mathrm{C}=3$ = severe hyperkeratosis, $\mathrm{D}=4=$ extensive hyperkeratosis.

Hyperkeratose Score bei 29 3-jährigen Holländischen Warmblutpferden. $A=$ geringgradige Hyperkeratose, $B=$ mittelgradige Hyperkeratose, $C$ = ausgeprägte Hyperkeratose, $D=$ hochgradige Hyperkeratose
Data and Statistical analysis

All data are given as mean \pm s.e. Following analysis of data for central tendency and for normal distribution, the Kruskal Wallis Test was used to determine significant differences between the scores (GENSTAT, 2001).

\section{Results}

All horses remained healthy during the investigation period and there were no outward clinical signs, which could be related to EGUS. Although there was no haylage or concentrate feed available from the point of withdrawal of food prior to gastroscopy, some horses did manage to rub off the muzzle and had to be re-fasted for 12 hours two days later to perform the first gastroscopy. However, in horses that had not rubbed off the muzzle, an unexpected high amount of ingesta was encountered during the first gastroscopic examination. After 12 hours fasting, in 10 of the 15 horses in the HF group a considerable amount of ingesta was visible during gastroscopy, compared to only 3 of the 14 horses in the LF group. In four horses in the HF group up to $25 \%$ of gastric volume was occupied by ingesta, in two horses a filling of about $50 \%$ was observed and in four horses more than $75 \%$ of the volume was filled. In the LF group two horses had retained food in approximately $25 \%$ of their stomach volume and one horse retained more than 75\%. In the LF group the contents appeared more like wood shavings and faeces (Figure

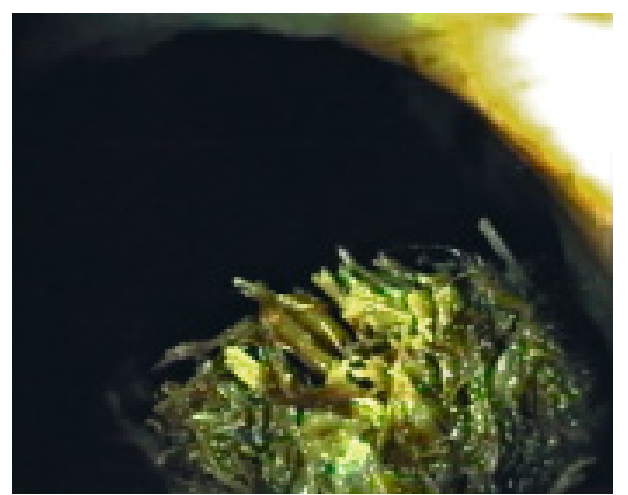

Fig 2 A high amount of stomach content, mainly shavings and manure.

Viel Mageninhalt, hauptsächlich Einstreu

2), whereas in the HF group a high amount of haylage was retained (Figure 3). In the few cases in which the non-glandular and glandular mucosa could not fully be interpreted (75\% stomach fill), the horses were two days later re-fasted for 12 hours and examined.

Behavioural observation conducted for one week of each training phase confirmed that a considerable amount of coprophagy and bedding eating occurred by individuals in the LF group (Ellis et al. 2003).

During the second gastroscopy, after the Pasture Period, some horses also showed some retention of stomach contents, but this was considerably less than after the Training Period.

Despite some retained gastric content, in all horses a thorough examination of the stomach lining could be performed. 
No severe lesions were present in any of the horses during any of the examinations. Most ulcers were seen in the nonglandular squamous mucosa of the stomach. Both after the Training Period and after the Pasture Period, one horse showed one superficial glandular lesion, but these were two different horses.

After the Training Period, the HF-group showed compared to the LF-group (Figure 4) a significantly higher score for the number of lesions ( $p=0.044$ ) and for hyperkeratosis ( $p=$ 0.013). Following the Pasture Period, there was no difference in scores between horses previously assigned to the LF- and HF-groups.

Comparing the results of the HF-group after the Training period with the results after the Pasture period, there were no sig-

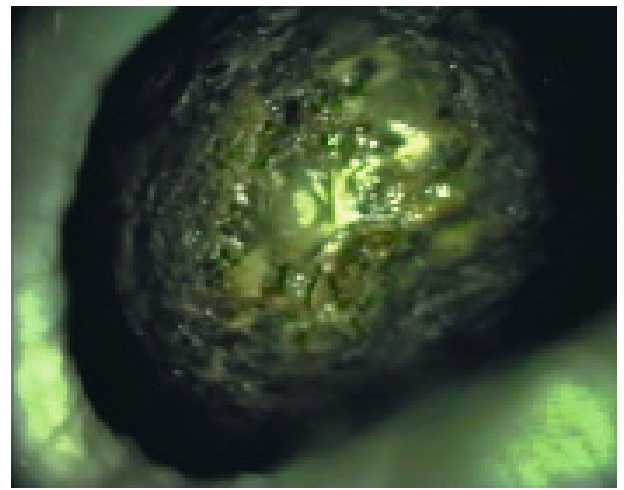

Fig 3 A high amount of stomach content, probably silage. Viel Mageninhalt, vermutlich Silage.

nificant differences. However, the LF-group showed significantly higher scores for 'overall score' ( $p=0.025)$, for 'number of lesions' ( $p=0.001$ ), for 'severity of lesions' ( $p=$ $0.001)$ and for 'hyperkeratosis' ( $p=0.001)$ after the Pasture period compared with after the Training period.

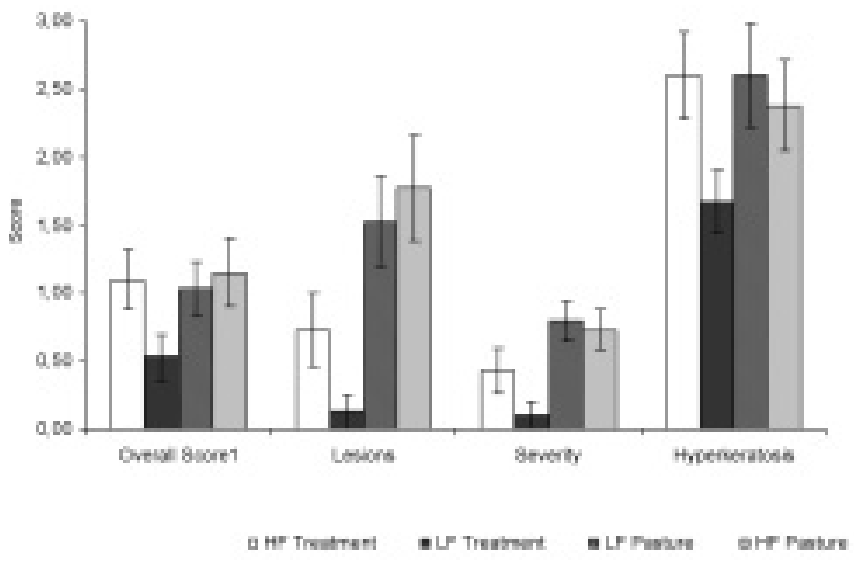

Fig 4 Mean overall clinical score, lesions, severity and hyperkeratosis after Training period (HF and LF-groups) and after Pasture period (HF- and LF-groups - now at same feed regime) in twenty-nine 3year old Dutch Warmblood horses.

Mittlerer Allgemeinscore, Läsionen, Ausprägung und Hyperkeratose nach Trainingsperiode (HF- und LF-Gruppen) und nach Weidegang (HF- und LF-Gruppen - jetzt beim gleichen Fütterungsprogramm) bei neununzwanzig 3-jährigen Holländischen Warmblutpferden.
Comparing the mean results of all horses after the Training period with the mean results of all horses after the Pasture period, the 'overall score' ( $0.8 \pm 0.2$ and $1.1 \pm 0.2$ respectively) and the 'hyperkeratosis' $(2.1 \pm 0.3$ and $2.5 \pm 0.3$ respectively) did not differ significantly, but the 'number of lesions' (0.4 \pm 0.2 and $1.6 \pm 0.3$ respectively) and the 'severity of lesions' $(0.3 \pm 0.1$ and $0.8 \pm 0.1$ respectively) were significantly higher ( $p=0.001$ for both).

\section{Discussion}

The gastroscopy study was part of a larger trial, in which the influence of increasing diet and exercise levels on physiological and behaviour parameters in a total of 36 3-year old Dutch Warmblood horses were investigated. Therefore, several circumstances were sub-optimal to help counter any possible biases within the gastroscopy study. Ideally, a gastroscopy prior to the Training period to investigate the appearance of gastric ulceration, would have given the possibility to divide the horses over the HF- and LF-groups taking these gastroscopy results into account. However, this was, not possible, as the horses were already divided for the larger study. Additionally, there was no opportunity to conduct a cross-over design to determine the response of individual horses to each diet. Despite these shortcomings, the number of horses with an identical age and history of nutrition, housing and training from birth, made the gastroscopic examinations useful as many previously reported studies on gastric ulcers in sports horses have not had the benefit of identical age, breed, sex distribution, exercise and diet levels for comparison between groups. Moreover, each horse acted as its own control between the two testing periods.

None of the horses showed any outward clinical signs of EGUS during the study. This finding possibly was related to the absence of any severe gastric ulceration. In contrast to previous investigations (Murray 1994) where high-concentrate diets have been reported as an important factor leading to the development of gastric ulcers in the non-glandular mucosa, in the present study the LF-diet did not lead to either a higher number of gastric ulcers or an increased severity.

Training was not considered an important factor in the present study as the Dutch Warmblood horses only worked to a medium-heavy level, whereas in most other studies Thoroughbreds working at top level have been used.

It is believed that salivary bicarbonate and the buffering effect of roughage (structural fibre) is responsible for an increased $\mathrm{pH}$ in cases of constant hay feeding, compared to withholding feed (Smyth et al. 1998). Constant access to good quality hay or alfalfa also helps to raise the $\mathrm{pH}$ in the stomach (Murray and Eichorn 1996b).

The behavioural study, which was part of the large experiment and published earlier (Ellis et al. 2006), showed that a considerable amount of coprophagy and 'bedding eating' was carried out amongst the LF group. The lack of fibre eaten by horses in the LF-group may have led to this increased coprophagy and bedding eating observed and could thus lead to an increase in saliva production, 'unaccounted' fibre intake and consequently a higher gastric $\mathrm{pH}$, minimizing the risk of 
ulcer development in this group of horses. However, this does not explain the significantly higher 'overall score' and 'number of lesions' after the Pasture period.

In most gastroscopy studies, a mean period of 10-12 hours fasting, is normally enough for gastric emptying (Vatistas et al. 1999). However, in horses of the HF-group, that were fed a considerable amount of haylage (DM 54\%), a large amount of ingesta was still present in the stomach after a minimum of 12 hours of fasting. This was also contrary to expectation and may have been related to the high haylage content of the diet.

The results of the present study may indicate that gastric emptying rates decreased considerably overnight, possibly allowing for greater fermentation of forage taking place in the stomach, than previously thought. Throughout the Training period, horses were fed for the last time at 17.00 hours and fed again at 08.00 hours the next morning and there was therefore a period of \pm 13 hours fasting every night. Thus during fasting, the pre-fermented haylage in the stomach may have been fermented further with an increase in bacterial population, leading to an increased release of volatile fatty acids (VFA's). The in vitro experiment by Nadeau et al. (2003) showed a decrease in the stomach barrier function and sodium transport in response to exposure to volatile fatty acids. If haylage was retained for longer periods then an increase in bacterial population and fermentation of this 'pre-fermented' forage may have occurred. Nadeau et al. (2003) found histopathological evidence of cellular swelling in all layers of the non-glandular mucosa after bathing the tissues in the VFA's valeric, acetic, propionic, and butyric acids. This suggested that at a low $\mathrm{pH}$, these VFA's can, themselves cause significant acid damage to the non-glandular squamous mucosa. Further, in vivo research is necessary to follow up this theory, particularly in relation to feeding of pre-fermented forage.

Thus, the difference in gastrocopy scores between the horses in the LF-group and the HF-group after the Training period are probably due to a combination of type of fibre fed and to additional manure and bedding intake of horses on the LFdiet. This theory is supported by the fact that after the Pasture period all horses developed similar lesion and hyperkeratosis scores as were found in the HF-group previously. This may be caused by the fact that haylage had to be made available at near 'ad libitum' levels (mean $11 \mathrm{~kg} /$ horse/day) because of the very dry weather. Therefore, it is possible that, due to the composition and the retention of haylage in the stomach of horses from the HF-group and all horses after the Pasture period, increased fermentation and acidity levels thus were responsible for the unexpected findings. Unfortunately due to weather circumstances and logistic constraints, it was impossible to add a further period on a grass diet only.

Although the present gastroscopic study encountered unexpected factors as coprophagy and bedding eating in the LFgroup and the necessity to feed additional haylage during the Pasture period, it highlights some interesting aspects of the effects of nutrition on the development of stomach ulcers. Firstly, the very consistent coprophagy and shavings eating observed in young Dutch Warmblood horses on a low-fibre diet needs to be noted, as it may occur unnoticed in practice. This behaviour may act as a 'protective' factor against deve- loping the severity of ulcers reported earlier in other studies with Thoroughbred horses. Secondly, the unexpectedly high retention of ingesta in the stomach after 12 hours fasting in horses on a high-haylage diet may have caused the higher number and severity of ulceration. Until further investigations have clarified the effects of a high-haylage diet, it may be advisable to keep horses prone to EGUS on a hay diet.

\section{References}

Andrews F. M., Bernard W., Byars D., Cohen N., Divers T., MacAllister C. and Pipers F. (1999): Recommendations for the diagnosis and treatment of equine gastric ulcer syndrome (EGUS). Equine Vet. Educ. 1,122-134

Bertone J. J. (2000): Prevalence of gastric ulcers in elite heavy use western performance horses. Proc. Am. Assoc. Equine Pract. 46, 256-259

Campbell-Thompson M. L. and Merritt A. M. (1990): Basal and pentagastrin-stimulated gastric secretion in young horses. Am. J. Physiol. 259, 1259-1266

Centraal Veevoederbureau (1996): Het definitieve VEP_en VREp_systeem. In: Documentatie rapport nr. 15

Coenen M. (1992): Beobachtungen zum Vorkommen von Magenulzera beim Pferd. Pferdeheilkunde 8, Supplement 1, 188-191

Deegen E., Ohnesorge B., Dieckmann M. und Stadler P. (1992): Ulzerative Gastritis beim Pferd. Pferdeheilkunde 8, Supplement 1, 183-187

De Fombelle A., Varloud M., Goachet A. G., Jacotot E., Philippeau C., Drogoul C. and Julliand V. (2003) Characterization of the microbial and biochemical profile of the different segments of the digestive tract in horsess given two distinct diets. Animal Science, 77, 293-304

Dörges F., Deegen E. und Lundberg J. (1995): Magenläsionen beim Pferd - Hohe Inzidenz bei gastroskopischen Untersuchungen. Pferdeheilkunde 11, 173-184

Ellis A. D., H. W. Merkens, E. K. Visser, M. B. H. Schilder and C. G. van Reenen (2003): Effects of high concentrate versus high fibre diets on equine digestive parameters in relation to performance, animal behaviour and welfare. 54th Annual meeting of the European Association of Animal Science, 1 st -3rd September, Rome, p. 416, Wageningen Academic Publishers

Ellis A. D., Visser E. K., Schilder M. B. H. and van Reenen C. G. (2006): The effect of high fibre versus low fibre diet on behaviour in horses. 40th International Conference of the Society for Applied Ethology, Bristol, 8th-1 1 th August 2006, p. 42, Cranfield University Press

Feige K., Fürst A. and Eser M. W. (2002): Effects of housing, feeding and use on equine health with emphasis on respiratory and gastrointestinal diseases. Schweiz Arch. Tierheilkd. 144, 348355

Hammond C. J., Mason D. K. and Watkins K. L. (1986): Gastric ulceration in mature Thoroughbred racehorses. Equine Vet. J. 18, 284- 287

Lundberg J., Jensen A. und Deegen E. (1996): Läsionen in der Magenschleimhaut beim Fohlen - klinische und endoskopische Befunde. Pferdeheilkunde 12, 267-270

MacAllister C. G., Andrews F. M., Deegan E., Ruoff W. and Olovson S. G. (1997): A scoring system for gastric ulcers in the horse. Equine Vet. J. 29, 430-433

McClure S. R., Glickman L. T. and Glickman N. W. (1999): Prevalence of gastric ulcers in show horses. J. Am. Vet. Med. Assoc. 215, 1130-1133

Meyer H., Ahlswede L. and Pferdekamp M. (1980): Investigations on stomach empty and the composition of stomach content in horses. Dtsch. Tierarztl. Wochenschr. 87, 43-47

Murray M. J. (1989): Endoscopic appearance of gastric lesions in foals: 94 cases (1987-1988). J. Am. Vet. Med. Assoc. 195, 1135 1141 
Murray M. J., Murray C. M., Sweeney H. J., Weld J., Digby N. J. and Stoneham S. J. (1990): Prevalence of gastric lesions in foals without signs of gastric disease: an endoscopic survey. Equine Vet. J. $22,6-8$

Murray M. J and Schusser G. F. (1993): Measurement of 24-h gastric $\mathrm{pH}$ using an indwelling $\mathrm{pH}$ electrode in horses unfed, fed and treated with ranitidine. Equine Vet. J. 25, 417-421

Murray M. J. (1994): An equine model of inducing alimentary squamous epithelial ulceration. Dig. Dis. Sci. 39, 2530-2535

Murray M. J., Schusser G. F., Pipers F. S. and Gross S. J. (1996a): Factors associated with gastric lesions in Thoroughbred racehorses. Equine Vet. J. 28, 368-374

Murray M. J. and Eichorn E. S. (1996b): Effects of intermittent feed deprivation, intermittent feed deprivation with ranitidine administration, and stall confinement with ad libitum access to hay on gastric ulceration in horses. Am. J. Vet. Res. 57, 1599-160

Murray M. J., Nout Y. S. and Ward D. L. (2001): Endoscopic findings of the gastric antrum and pylorus in horses: 162 (1996-2000). J. Vet. Intern. Med. 14. 401-406

Nadeau J. A., Andrews F. M., Mathew A. G., Argenzio R. A., Blakkford J. T., Sohtell M. and Saxton A. M. (2000): Evaluation of diet as a cause of gastric ulcers in horses. Am. J. Vet. Res. 61, 784790

Nadeau J. A., Andrews F. M., Patton C. S., Argenzio R. A., Mathew A. G. and Saxton A. M. (2003). Effects of hydrochloric, acetic, butyric, and propionic acids on pathogenesis of ulcers in the nonglandular portion of the stomach of horses. Am. J. Vet. Res. 64, 404-412
Rabuffo T. S., Orsini J. A., Sullivan E., Engiles J., Norman T. and Boston R. (2002): Association between age or sex and prevalence of gastric ulceration in Standardbred reacehorses in training. J. Am. Vet. Med. Assoc. 221, 1156-1159

Ross I. N., Bahari H. M. and Turnberg L. A. (1981): The $\mathrm{pH}$ gradient across mucus adherent to rat fundic mucosa in vivo and the effect of potential damaging agents. Gastroenterology 81, 713-718

Roy M. A., Vrins A., Beauchamp G. and Doucet M. Y. (2005) Prevalence of ulcers of the squamous gastric mucosa in standardbred horses. J. Vet. Intern. Med., 19, 744-50.

Smyth G. B., Young D. W. and Hammond L. S. (1998): Effects of diet and feeding on postprandial serum gastrin and insulin concentration in adult horses. Equine Vet. J. Suppl. 7, 56-59

Vatistas N. J., Snyder J. R., Carlson G., Johnson B., Arthur R. M., Thurmond M., Zhou H. and Lloyd K. L. (1999): Cross-sectional study of gastric ulcers of the squamous mucosa in Thoroughbred racehorses. Equine Vet. J. 29, 34-39

Dr. Maarten Boswinkel

Department of Equine Sciences

Faculty of Veterinary Medicine

Utrecht University

Yalelaan 174

3584 CM Utrecht

The Netherlands

m.boswinkel@vet.uu.nl

\title{
Sonographische Diagnostik Johannes Edinger und Doreen Scharner
}

\author{
10.- 11 März, Humboldt-Universitäł Berlin
}

Typische Artefakte in der Sehnen- und Gelenkdiagnostik Sonoanatomie und Diagnostik der Beugesehnen und des Fesselträgers Sonographie der Fesselbeuge

Sonographische Befunde bei Sehnenscheidenerkrankungen Sonographisch kontrollierter Heilungsverlauf von Sehnenschäden Sonoanatomie und Untersuchungstechnik von Fessel-, Karpal-, Tarsal- und Kniegelenk Sonographische Untersuchung und Befunde der Schulter- und Beckenregion Befunde der Gelenksonographie

Transrektale Sonographie des Lumbo- und Iliosacralgelenkes Sonographisch geführte Punktion und intraoperative Sonographie

Ultraschalluntersuchung der Speiseröhre und V. jugularis

Sonographie parenchymatöser Organe und des Harnapparates

Sonographische Befunde unklarer Umfangsvermehrungen Abdominale Sonographie: Gastrointestinale Normalbefunde und sonographisch unterstützte Kolikdiagnostik Interpretation sonographischer Befunde in Bezug zu klinischen Kolikbefunden

Urachusfisteln und Nabelhernien mit sonographischer Unterstützung Diagnose umbilikaler Infektionen

\section{www.curricula.cc}

